\title{
Article \\ Carbon Storage along with Soil Profile: An Example of Soil Chronosequence from the Fluvial Terraces on the Pakua Tableland, Taiwan
}

\author{
Chin-Chiang Hsu ${ }^{1} \mathbb{1}$, Heng Tsai ${ }^{1, *}$, Wen-Shu Huang ${ }^{2}$ and Shiuh-Tsuen Huang ${ }^{3}$ \\ 1 Department of Geography, National Changhua University of Education, Changhua 500, Taiwan; \\ d0343002@gm.ncue.edu.tw \\ 2 Center for General Education, National Chung Cheng University, Chiayi 621, Taiwan; \\ cgesoil@alum.ccu.edu.tw \\ 3 Department of Science Education and Application, National Taichung University of Education, \\ Taichung 403, Taiwan; hstsuen@mail.ntcu.edu.tw \\ * Correspondence: geotsaih@cc.ncue.edu.tw
}

Citation: Hsu, C.-C.; Tsai, H.; Huang, W.-S.; Huang, S.-T. Carbon Storage along with Soil Profile: An Example of Soil Chronosequence from the Fluvial Terraces on the Pakua Tableland, Taiwan. Land 2021, 10, 447. https://doi.org/10.3390/ land10050447

Academic Editor: Agata Novara

Received: 16 March 2021

Accepted: 20 April 2021

Published: 23 April 2021

Publisher's Note: MDPI stays neutral with regard to jurisdictional claims in published maps and institutional affiliations.

Copyright: (c) 2021 by the authors. Licensee MDPI, Basel, Switzerland. This article is an open access article distributed under the terms and conditions of the Creative Commons Attribution (CC BY) license (https:/ / creativecommons.org/licenses/by/ $4.0 /)$.

\begin{abstract}
A well-dated soil chronosequence may allow exploration of the accumulation of soil carbon over time. There are multiple levels of river terraces on the Pakua tableland in Central Taiwan. Unlike many of the reddish or lateritic soils in Taiwan, these soils were recently dated, with absolute ages in the range of 19-400 kyr. This information allowed us to develop an ideal soil chronosequence, with time constraints, through which it is possible to explore soil organic carbon (SOC) storage and its changes over time. In this study, we attempted to establish an SOC time series, and to give an estimate of long-term accumulation of the SOC storage in the red soils of Taiwan. The data on these soils used in this study were taken from the soil profiles presented in our previous studies. Two additional soil profiles were sampled for those soils for which data were not available from the previous studies. The total carbon stock (TCS) for each soil profile was measured and assessed based on the depth categories of 0-30, 30-50, and 50-100 cm. Weighted carbon stock (WCS) measurements were further derived by the total thickness of the soil profile, for better comparison. The overall carbon stocks of the soils in the Pakua tableland were in the range of 2.8-3.2 Tg for TCS and WCS, respectively. In addition, the SOC tended to be highest in the surface soil horizons and decreased with the soil depth. The continuous pattern of the carbon content, in terms of its vertical distribution, was considered in terms of a negative exponential function, which showed that the SOC was highest in the shallowest soil layers and decreased rapidly with the soil depth. This trend was mitigated at a depth of 50-100 cm, which approached a fixed value, denoted as the carbon sequestration value (CSV), below a certain depth. We show here that the values of the CSV, as approximated by exponential fitting, are closely related to soil age. The CSV linearly decreases with age. These findings point to the potential of using carbon storage for chronometric applications.
\end{abstract}

Keywords: soil organic carbon; carbon stocks; soil chronosequence; Pakua tableland

\section{Introduction}

Soil is the largest active terrestrial reservoir in the global carbon cycle. Unfortunately, this system is affected and can be interfered with by human activities. The amount of organic carbon in soil is approximately three times that in the atmosphere [1,2]. Lal [3] estimated that the potential soil organic carbon (hereafter, SOC) sequestration that could occur globally, through proper management or restoration of land use, may offset one third of the annual increase in atmospheric $\mathrm{CO}_{2}$. The content of SOC and its stability depends on factors, e.g., climate, topography, vegetation, and farming, as well as soil texture, depth, drainage, and soil horizons [4-7].

Most studies on carbon storage in soil have considered the SOC at a shallow depth and compared changes that have occurred in recent decades [8]. Studies of the stability 
and the long-term changes of SOC are rare, and further study is needed. In fact, SOC has a long turnover period of decades to thousands of years, resulting in its prolonged presence in soil $[7,9,10]$. In addition, it is stable in soils deeper than $50 \mathrm{~cm}$, highlighting a depth-dependent process which couples soil development with long-term C cycling [7]. The positive relationship between non-crystalline minerals and organic carbon in soils, evidenced by the climate gradient, indicates that the accumulation and subsequent loss of organic matter are largely driven by changes in the millennial-scale cycling of mineralstabilized carbon, rather than changes in the amount of fast-cycling organic matter or the net primary productivity [11]. Records of progressive changes in SOC over longer time scales would thus facilitate a better understanding of long-term carbon storage.

Soils developed on river terraces, which form a soil chronosequence, may represent a solution to this challenge. For instance, there are well-developed river terraces with multiple levels of surfaces on the Pakua tableland in Central Taiwan. Their surfaces are covered with lateritic soils, whose ages range from 19 to $400 \mathrm{kyr}$ [12,13]. This provides a suitable time scale for analysis of SOC storage and soil depth, thereby enabling researchers to establish an SOC time series and to explore the long-term accumulation and storage rates of SOC. Unfortunately, the existing studies on soil carbon stocks in Taiwan have mainly focused on estimating carbon stocks in different woodlands or for land use in alpine regions $[14,15]$. These studies have shown that more than two thirds of the SOC is localized at the surface layers, within a depth of $30 \mathrm{~cm}$, and that the SOC decreases with depth [15-17]. This pattern is commonly observed in soils [18]. The SOC concentrations of shallow topsoil do not indicate this and cannot be used to estimate the actual carbon mass of a given area [19], and neither are they indicative of the SOC's stability or retention. Lawrence et al. [7] analyzed the SOC of shallow soil $(<50 \mathrm{~cm})$ and deep soil $(>50 \mathrm{~cm})$ and found that the shallow horizon of relatively young soil (11-60 kyr) had relatively high carbon concentrations, whereas the SOC of older soil (150-500 kyr) was concentrated at deeper soil horizons. In fact, the SOC content changes as soil ages. Quantification of the patterns and thresholds in soil development should improve our understanding of SOC cycling with depth and/or time, laying the foundation for models that accurately represent deep- and slow-cycling SOC.

In this study, we not only explore long-term stable carbon retention at deep soil horizons but also discuss the relationship between the soil pedogenesis and soil carbon sequestration of the surface deposits of a river terrace. It may provide an alternate scheme of relative dating for geomorphic correlation purposes.

\section{Study Area and Site}

\subsection{Geology and Topography}

The Pakua tableland is located in Central Taiwan. It is bordered to the south by the Jwoshoei River, to the north by the Wu River, to the west by the Changhua coastal plain, and to the east by the Taichung Basin. The tableland is $100-450 \mathrm{~m}$ above sea level and stretches from the northwest to the southeast (Figure 1). The Pakua tableland belongs to the deformation zone at the forefront of Taiwan's western orogenic belt. A series of east-facing faults are arranged in a tiling pattern, with the Shuilikeng, Shuangtung, Chelungpu, and Changhua Faults arranged from east to west. The Changhua Fault is located at the western edge of the Pakua tableland, which is located on the hanging wall of the fault $[20,21]$. The main strata that form the Pakua tableland are the Pleistocene Toukoshan formation and the Quaternary lateritic fluvial gravel deposits (Supplementary Materials Figure S1). On the Toukoshan formation, in the northern part of the plateau, layers of sandstone can be observed, and a few of these contain conglomerate interlayers. In the south-central part of the plateau, there are thick layers of conglomerate, and a few of these contain thin sandstone interlayers [20,22]. 

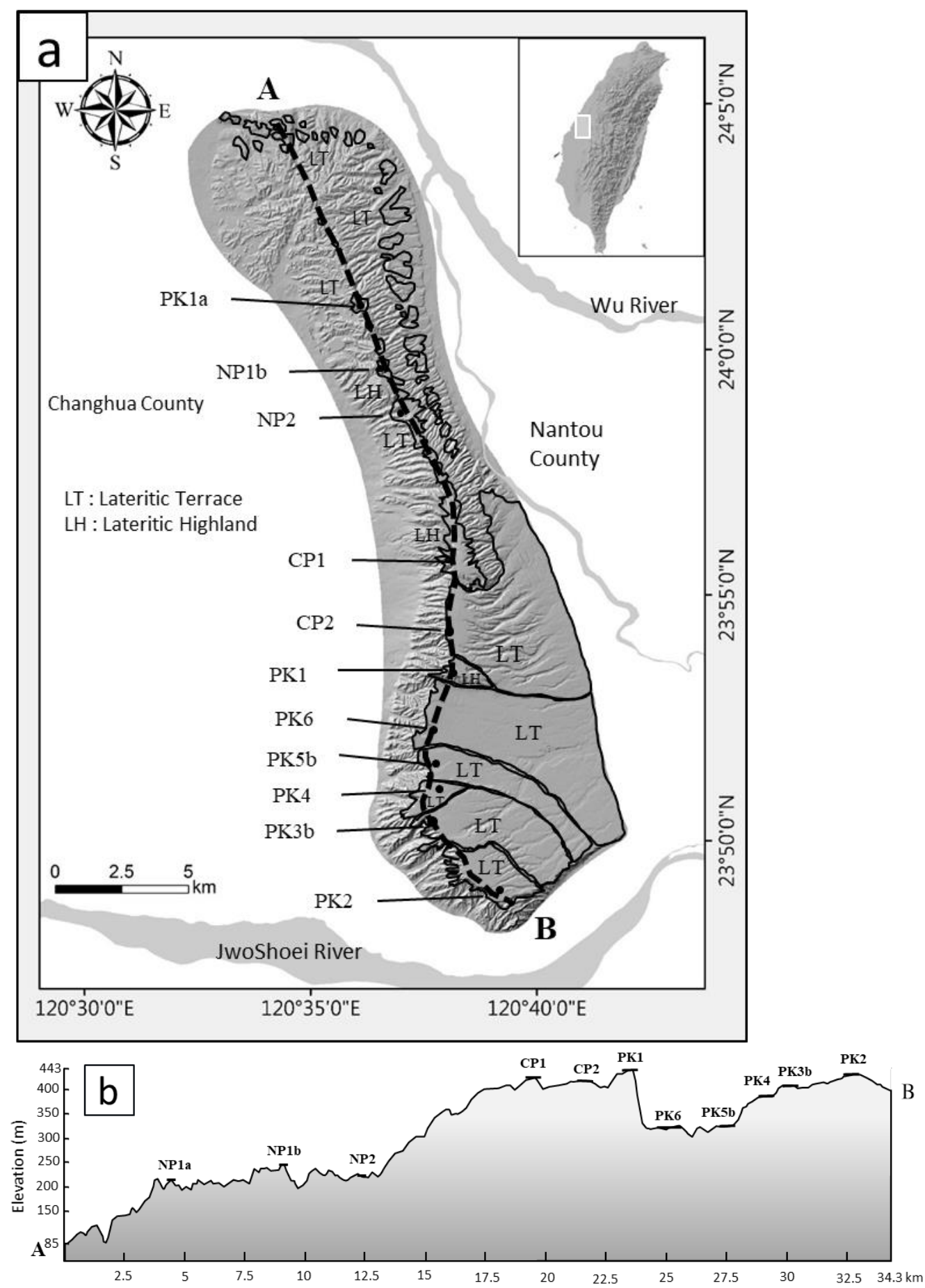

Figure 1. (a) Pakua tableland topographic map and sampling point, and (b) topographical profile (A-B) and soil age distribution.

The Pakua tableland was originally an alluvial fan that was formed by the western foothills in the western upthrust fault mountains. Seismic activity in the Changhua Fault caused the plateau to rise, and while it was rising, the plateau experienced erosion and accumulation due to the influence of the Wu River, Jwoshoei River, and other local tributaries, resulting in the development of the river terrace [23]. The highest terrace on the river terrace is Henshan, which is located in the center of the plateau (Figure 1). The terrace developed in the northern part of the plateau (north of Henshan) and suffered intensive erosion, with only a small part remaining along the hinge of the anticline today. There are wide, relatively well-preserved, flat river terraces located in the southern area of the 
plateau, with height decreasing from south to north. This area can clearly be distinguished as a six-step, asymmetrical river terrace topographical formation [23] (Table 1).

Table 1. Pakua tableland soil type distribution and age.

\begin{tabular}{|c|c|c|c|c|c|}
\hline Location & Pedon/Location ${ }^{1}$ & Elevation $^{2}(\mathrm{~m})$ & $\begin{array}{l}\text { Age }{ }^{3} / \text { Dating } \\
\text { Method }^{4} \text { (kyr) }\end{array}$ & Soil Types ${ }^{5}$ & Land Use $^{2}$ \\
\hline Yinhangshan & $\begin{array}{c}\mathrm{NP} 1 \mathrm{a} \\
120.584022 \mathrm{E} \\
24.041304 \mathrm{~N}\end{array}$ & 243 & $340 / a$ & Typic Hapludox & Fruit garden, mixed forest \\
\hline Nanfengliao & $\begin{array}{c}\text { NP1b } \\
120.593026 \mathrm{E} \\
24.016922 \mathrm{~N}\end{array}$ & 256 & $400 / \mathrm{b}$ & Typic Hapludox & Areca, chicken coop \\
\hline Touchouliao & $\begin{array}{c}\text { NP2 } \\
120.603512 \mathrm{E} \\
23.992218 \mathrm{~N}\end{array}$ & 231 & $335 / b$ & Typic Hapludox & Fruit garden, mixed forest, areca \\
\hline Liufenliao & $\begin{array}{c}\mathrm{CP} 1 \\
120.628242 \mathrm{E} \\
23.943367 \mathrm{~N}\end{array}$ & 426 & $400 / b$ & Typic Hapludox & Fruit garden, areca, tea garden \\
\hline Shichopin & $\begin{array}{c}\mathrm{CP} 2 \\
120.624465 \mathrm{E} \\
23.910887 \mathrm{~N}\end{array}$ & 419 & $335 / b$ & Typic Hapludox & Fruit garden, areca, tea garden \\
\hline Henshan & $\begin{array}{c}\text { PK1 } \\
120.6309 \mathrm{E} \\
23.8936 \mathrm{~N}\end{array}$ & 443 & $400 \pm 50 / c$ & Typic Kandiudult & Fruit garden, tea garden \\
\hline Dachuang & $\begin{array}{c}\text { PK6 } \\
20.6253 \mathrm{E} \\
123.8833 \mathrm{~N}\end{array}$ & 320 & $19 \pm 2 / a$ & Typic Dystrudepts & Fruit garden, tea garden \\
\hline Chshuei & $\begin{array}{c}\text { PK5b } \\
120.6190 \mathrm{E} \\
23.8595 \mathrm{~N}\end{array}$ & 330 & $31 / \mathrm{d}$ & Typic Dystrudepts & Tea garden \\
\hline Gungshie & $\begin{array}{c}\text { PK4 } \\
120.6295 \mathrm{E} \\
23.8555 \mathrm{~N}\end{array}$ & 386 & $164 \pm 48 / \mathrm{e}$ & Typic Dystrudepts & Tea garden, pineapple garden \\
\hline Sungbokang & $\begin{array}{c}\text { PK3b } \\
120.6194 \mathrm{E} \\
23.8415 \mathrm{~N}\end{array}$ & 410 & $267 \pm 65 / \mathrm{e}$ & Typic Paleudult & Tea garden, areca \\
\hline Pujung & $\begin{array}{c}\text { PK2 } \\
120.6462 \mathrm{E} \\
23.8555 \mathrm{~N}\end{array}$ & 431 & $335 \pm 77 / \mathrm{e}$ & Typic Paleudult & Fruit garden, areca \\
\hline
\end{tabular}

${ }^{1}$ The codes NP1a, NP1b, NP2, CP1, and CP2 are identical to those from Huang et al. [19], while PKN-1a, PKN-1b, PKN-2a, PKN-1c, and PKN-2b. PK1-PK6 are based on Tsai et al. [18]. ${ }^{2}$ Based on Huang et al. [19]. ${ }^{3}$ For the absolute ages of NP1a and PK6, refer to Simoes et al. [24]; for PK1, PK2, PK3b, PK4, and PK5b refer to Tsai et al. [18]. ${ }^{4}$ a: Optically stimulated luminescence (OSL); b: based on the weighted mean of the profile development index (WPDI) compared to PK1 and PK2; $\mathrm{c}: \mathrm{Be}^{10}$; $\mathrm{d}$ : based on pedologic correlation; and e: interpolated from relationships between WPDIs and soil ages. ${ }^{5}$ For the soil types of NP1a, NP1b, NP2, CP1, and CP2 refer to Huang et al. [19]; for PK1, PK2, PK3b PK4, PK5b, and PK6 refer to Tsai et al. [18].

\subsection{Climate and Vegetation}

According to the Central Meteorological Administration of Taiwan, the mean annual temperature of the Pakua tableland from 2012 to 2017 was $23.3^{\circ} \mathrm{C}$, with the highest temperatures recorded in July and August, and the lowest temperatures recorded in January. The average monthly temperatures ranged from $16.4{ }^{\circ} \mathrm{C}$ (January) to $28.4{ }^{\circ} \mathrm{C}$ (July). The current mean annual precipitation is $1892 \mathrm{~mm}$, with the highest volume of rainfall recorded during June and August, and the lowest volume of rainfall recorded in October. Throughout the year, rainfall greatly exceeds evapotranspiration, thereby keeping the soil moist all year round. Under these climatic conditions, the soil is hyperthermic and udic. 
The natural vegetation, covering about $58 \%$ of the tableland, has been greatly disturbed by human activities in recent decades. The remaining natural vegetation, including the primitive forests, accounts for less than $8 \%$ of the total vegetation [25]. The major agricultural crops in the area include tea and pineapple, with bamboo and longan, lychee, and areca trees sparsely distributed throughout the area.

\subsection{Soil Distribution and Age}

The Pakua tableland was originally an alluvial plain that was formed by the Wu and Jwoshoei Rivers during the Pleistocene Epoch of the Quaternary Period [18,26,27]. The subsequent uplift of the plateau by frontal thrusting of the Changhua Fault resulted in the oscillations and incisions of the Jwoshoei River. The surface deposits of fluvial sediments deposited at different times underwent various degrees of weathering [26,27]. As a result, the soils developed from these weathering products differ in age. This is in agreement with the post-incisive type of chronosequence defined by Vreeken [28]. It suggests a soil chronosequence of Inceptisol (Cambisols) to Ultisol (Acrisol), and to Oxisols (Ferralsols), in the order of increasing degree of pedogenesis [27]. For convenience, the soils and their distribution are arbitrarily divided into three distinct sections: north, central, and south, according to the topography of the plateau.

Although Liew [29] indicated that a lateritic weathering phase occurred in the most recent Pleistocene period, approximately $140 \mathrm{kyr}$ ago, given the major transgression associated with the last interglacial event, Simoes et al. [24] and Tsai et al. [18] have suggested that the terraces of Henshan, Yinhangshan, and Pujung are $>330,000$ years old. The youngest terrace, the Dachuang Step, was probably formed within the last 20,000 years (Table 1). The age of the red soil on these terraces, as well as their developmental chronosequences, serves as the supporting framework for research in the region. We applied these existing data to areas of the river terrace where soil data were incomplete or lacking (PK3 and PK5) and collected soil profiles from PK3b and PK5b (Figure 1), in order to conduct physical and chemical analyses to fully characterize the terrace soil (Supplementary Materials Table S1) [30].

\section{Methods}

\subsection{Estimation of Carbon Storage}

Representative soil profiles were sampled from each terrace pedon. Soils were sampled from the horizons described in the fields. They were air-dried and sieved to $<2 \mathrm{~mm}$ in the laboratory for further analysis. Bulk density (BD), as presented in Table S1, was determined using the paraffin block method [31]. The dried soil block was first weighted and fixed with filament. A film covered the surface of the block after it was submerged in liquefied paraffin at approximately $60{ }^{\circ} \mathrm{C}$. It was weighted again before and after it was immersed in water to measure the volume of the soil block. The mass of the soil block was further corrected by removing the weights of coarse gravels larger than $2 \mathrm{~mm}$ in size. The measurement of the organic carbon (OC) content followed the Walkley-Black wet oxidation process proposed by Nelson and Sommers [32].

The carbon storage of the soil was estimated using the bulk density, content of organic carbon, and horizon thickness in the following calculation [2,4,33,34]:

$$
\mathrm{TCS}=\sum_{i=1}^{k} B d_{i} \times O c_{i} \times D_{i} \times\left(1-S_{i}\right)
$$

TCS represents the total carbon stocks with the unit of $\mathrm{kg} \mathrm{m}^{-2} . B d_{i}\left(\mathrm{Mg} \mathrm{m}^{-3}\right)$ is the bulk density of the $i$ horizon of the soil profile. $O c_{i}\left(\mathrm{~g} \mathrm{~kg}^{-1}\right)$ is the organic carbon in the $i$ horizon. $D_{i}(\mathrm{~m})$ is the thickness of the $i$ horizon. $S_{i}(\%)$ is the proportion of gravel or particles $>2 \mathrm{~mm}$ in size in the $i$ horizon, which was extremely low $(<0.1 \%)$ and therefore not considered in this study. 
Since the soil profiles vary with depth, the soil carbon storage was normalized by the thickness of the soils in the assessment. As a result, weighted carbon stocks (WCS) were calculated for better comparison, as follows:

$$
\mathrm{WCS}=\mathrm{TCS} / D_{t}
$$

where $D_{t}(\mathrm{~m})$ is the total depth of the soil profile. WCS $\left(\mathrm{kg} \mathrm{m}^{-3}\right)$ refers to the average amount of carbon stored in the volume of soil at a depth of $1 \mathrm{~m}$.

In fact, the amount of carbon in the soil changes with depth. There are mathematic approaches to approximating the pattern of the distribution $[4,35,36]$, which, in general, agree with the exponential relationship [34]. Here, we applied the negative exponential function to consider the continuous change in carbon in the soil with depth, as follows:

$$
\operatorname{ECS}\left(z_{i}\right)=C_{a} \operatorname{EXP}\left(-k z_{i}\right)+C_{b}
$$

where ECS $\left(z_{i}\right)\left(\mathrm{kg} \mathrm{m}^{-3}\right)$ denotes the exponential function of carbon stocks in the $i$ horizon. $z_{i}(\mathrm{~m})$ represents the thickness of $i$ horizon. $C_{a}$ is the carbon stock of a given horizon. $C_{b}$ is the carbon stock of the bottom horizon of the profile. Both $C_{a}$ and $C_{b}\left(\mathrm{~kg} \mathrm{~m}^{-3}\right)$ are obtained by multiplying the $B d\left(\mathrm{Mg} \mathrm{m}^{-3}\right)$ and $O c\left(\mathrm{~g} \mathrm{~kg}^{-1}\right)$, and $k$ is the rate of carbon decrease with depth.

\subsection{Soil Quantification Indices}

The soil quantification indices of the horizon index (HI) and profile development index (PDI), which quantify the field properties of soils, have been proven to be an easy and effective approach to study soil development rates and quantitatively compare the soil development of different parent materials and in different climatic regimes [37]. The weighted mean of the profile development index (WPDI), which provides a better comparison in terms of the degree of soil development, was applied to the regional correlation for geomorphic surfaces in this paper [27].

The soil properties of rubification, lightening, total texture, dry consistency, moist consistency, structure, and clay films were quantified by comparing to those of the parent materials. The HI was obtained by the summation of the quantified value, divided by the number of properties. The PDI is the sum of HI multiplied by soil depth of horizons. The PDI values were divided by the depth of the described soil profile to produce weighted mean PDI (WPDI) normalized values ranging between 0 (no development) and 1 (maximum development) [37,38].

\subsection{Statistical Analysis}

The statistical analyses of this study included the Pearson correlation coefficient, which measures the linear correlation between two sets of data. The results were based on calculations from the SPSS (IBM Corporation, New York, NY, USA) package. The variables used in the analyses included the CSV, TCS, WCS, CAR, and soil age.

\section{Results}

\subsection{Carbon Stocks and Vertical Distribution}

The bulk densities of the soils were within the range of $1.25-1.6 \mathrm{Mg} \mathrm{m}^{-3}$ (Supplementary Materials Figure S2); however, the content of organic carbon decreased rapidly from the surface horizon. There were sharp transitions toward a gentle slope in the pattern at a depth of approximately $50-100 \mathrm{~cm}$. The total carbon stock (TCS) was calculated at three different depths: 0-30, 30-50, and 50-100 cm, based on Equation (1) (Table 2). 
Table 2. Pakua tableland carbon stock calculation and estimation values for each pedon.

\begin{tabular}{|c|c|c|c|c|c|c|c|}
\hline \multirow{2}{*}{ Pedon } & \multirow{2}{*}{$\operatorname{CSV}\left(\mathrm{kg} \mathrm{m}^{-3}\right)$} & \multirow{2}{*}{ TCS $\left(\mathrm{kg} \mathrm{m}^{-2}\right)$} & \multirow{2}{*}{ WCS $\left(\mathrm{kg} \mathrm{m}^{-3}\right)$} & \multicolumn{3}{|c|}{ Carbon Stock $\left(\mathrm{kg} \mathrm{m}^{-2}\right)$} & \multirow{2}{*}{$\operatorname{CAR}\left(\mathrm{g} \mathrm{m}^{-3} \mathrm{yr}^{-1}\right)$} \\
\hline & & & & $0-30(\mathrm{~cm})$ & $0-50(\mathrm{~cm})$ & 0-100 (cm) & \\
\hline NP1a & 5.04 & 21.24 & 6.25 & 1.34 & 3.51 & 4.84 & 0.018 \\
\hline NP1b & 6.57 & 16.77 & 9.87 & 6.28 & 7.93 & 11.66 & 0.020 \\
\hline NP2 & 10.57 & 29.39 & 14.70 & 6.80 & 9.70 & 17.01 & 0.036 \\
\hline $\mathrm{CP} 1$ & 3.89 & 11.85 & 5.93 & 2.16 & 2.64 & 4.55 & 0.020 \\
\hline $\mathrm{CP} 2$ & 7.19 & 17.54 & 11.31 & 3.88 & 6.28 & 12.61 & 0.036 \\
\hline PK1 & 2.80 & 15.17 & 7.59 & 6.91 & 8.35 & 11.23 & 0.019 \\
\hline PK2 & 8.96 & 19.69 & 13.58 & 6.55 & 8.84 & 15.05 & 0.041 \\
\hline PK3b & 9.99 & 33.73 & 21.07 & 9.21 & 15.00 & 25.64 & 0.079 \\
\hline PK4 & 11.71 & 15.96 & 15.96 & 6.93 & 10.19 & 15.96 & 0.097 \\
\hline PK5b & 12.99 & 23.37 & 16.69 & 6.21 & 9.41 & 17.49 & 0.539 \\
\hline PK6 & 14.40 & 16.73 & 14.67 & 4.99 & 8.18 & 14.71 & 0.772 \\
\hline
\end{tabular}

CSV: carbon sequestration value; TCS: total carbon stock; WCS: weighted carbon stock; CAR: carbon accumulation rate.

The sampling depth of each soil profile was different (NP1a was the deepest, at $310 \mathrm{~cm}$, and PK4 was the shallowest, at $100 \mathrm{~cm}$ ), with a mean thickness of $172 \mathrm{~cm}$ across 11 profiles (Supplementary Materials Table S1). It was difficult to compare differences in carbon storage patterns across the different fluvial terraces. Therefore, when calculating carbon storage, the effects of soil depth were considered by using the average depth for the WCS (Equation (2)). The trends in the TCS and WCS (Table 2) distributions were similar: PK3b and CP1, respectively, contained the largest and the smallest amounts of carbon stock. The TCS and WCS at different soil depths were compared to calculate the total carbon stock of the entire Pakua tableland, based on a total area of $221.56 \mathrm{~km}^{2}$. The TCS gives a larger estimate of the total carbon stock of the overall Pakua tableland than the WCS. For instance, the average values of the TCS $(0-100 \mathrm{~cm})$ and WCS, respectively, from the 11 profiles, were $14.28 \mathrm{~kg} \mathrm{~m}^{-2}$ and $12.51 \mathrm{~kg} \mathrm{~m}^{-3}$, giving a total carbon storage of 3.2 and $2.8 \mathrm{Tg}$ for the study area (Table 3). The WCS, however, gives a larger estimate of the total carbon stock when the average values of the TCS and WCS refer to the full thickness of the profile (Table 3). This result was expected, since the majority of the SOC is naturally confined to shallow soil layers $[10,11,36]$. For the top layers of the soil $(0-100 \mathrm{~cm})$, this estimate only represents the average carbon storage of the top layers of soil in the area that was investigated, not the average carbon storage throughout the entire study area.

Table 3. Comparison of different calculation methods for the Pakua tableland carbon stocks.

\begin{tabular}{ccc}
\hline TCS/WCS & Average of Carbon Stock $\left(\mathbf{k g ~ m}^{-\mathbf{2}}\right)$ & Pakua Tableland Carbon Storage $\mathbf{( T g )}$ \\
\hline TCS & & \\
$0-100 \mathrm{~cm}$ & 14.28 & 3.164 \\
full profile & 20.13 & 4.460 \\
WCS & & \\
$0-100 \mathrm{~cm}$ & 12.51 & 2.772 \\
full profile & 21.52 & 4.767 \\
\hline
\end{tabular}

\subsection{Carbon Accumulation Rate}

The bedrocks or the soils of the $\mathrm{C}$ horizon were not able to be collected for some soil profiles, because the profiles were sampled to the available depth without augering (Table S1). As a result, the TCS was calculated from the data of the soils from the surface to the available depth. The organic carbons in the deeper soils were ignored. The carbon accumulation rate (CAR) was derived by dividing the WCS value by the soil age, giving an average value of the carbon storage for a soil profile. For instance, PK6 yielded the greatest CAR value, with an average value of $0.772 \mathrm{~g} \mathrm{~m}^{-3} \mathrm{yr}^{-1}$, and NP1a yielded the lowest 
CAR value, with an average value of $0.018 \mathrm{~g} \mathrm{~m}^{-3} \mathrm{yr}^{-1}$ (Table 2), suggesting a negative relationship between soil age (kyr) and the CAR shown in Figure 2, as follows:

$$
\text { CAR }=0.7368 \mathrm{e}^{-0.009(\text { Age })}
$$

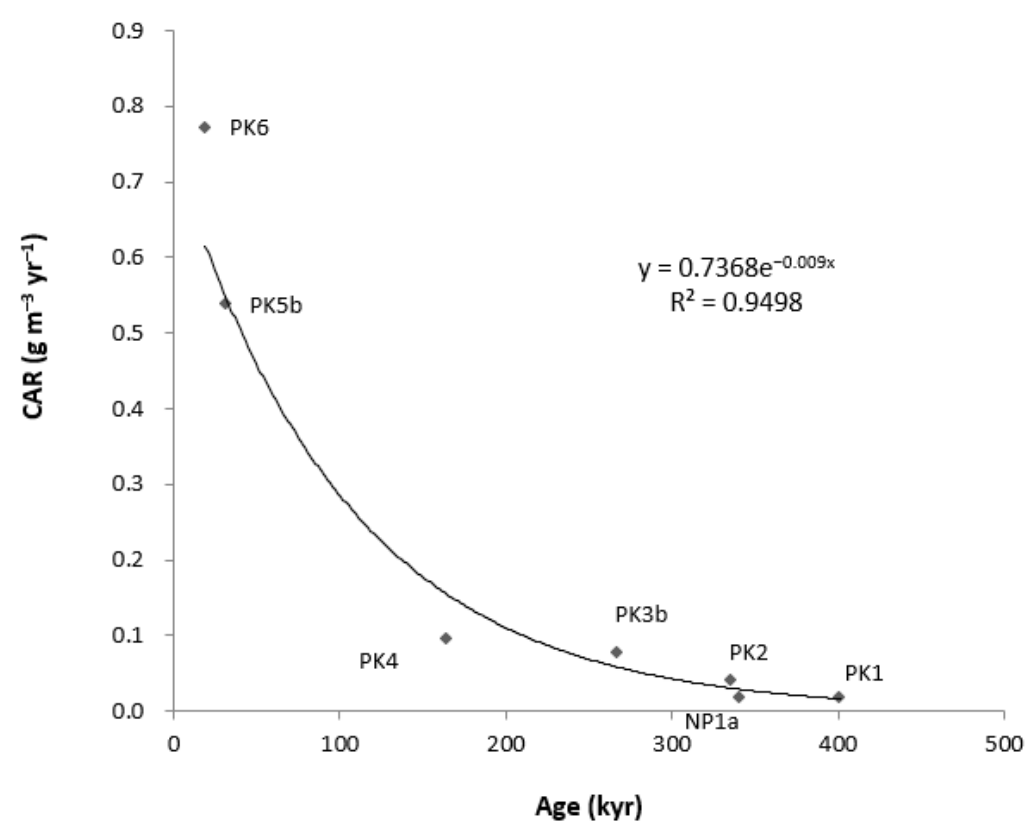

Figure 2. The Pakua tableland carbon accumulation rate (CAR) versus time for each pedon.

\subsection{Exponential Function of the Carbon Sequestration Value}

A negative exponential function (Equation (3)) was applied to fit the data of Supplementary Materials Table S1, which yielded a simulation of the vertical distribution of the organic carbon stock along the soil profiles. Observing the continuous variations in the vertical distribution of the SOC in the soil profiles (Figure 3) revealed that the SOC was highest in the shallowest soil layers and sharply decreased with soil depth. There was a sharp transition in the curve of SOC at 50-100 cm, and it reached a fixed value below a certain depth. The fixed value is termed the "carbon sequestration value" (CSV).

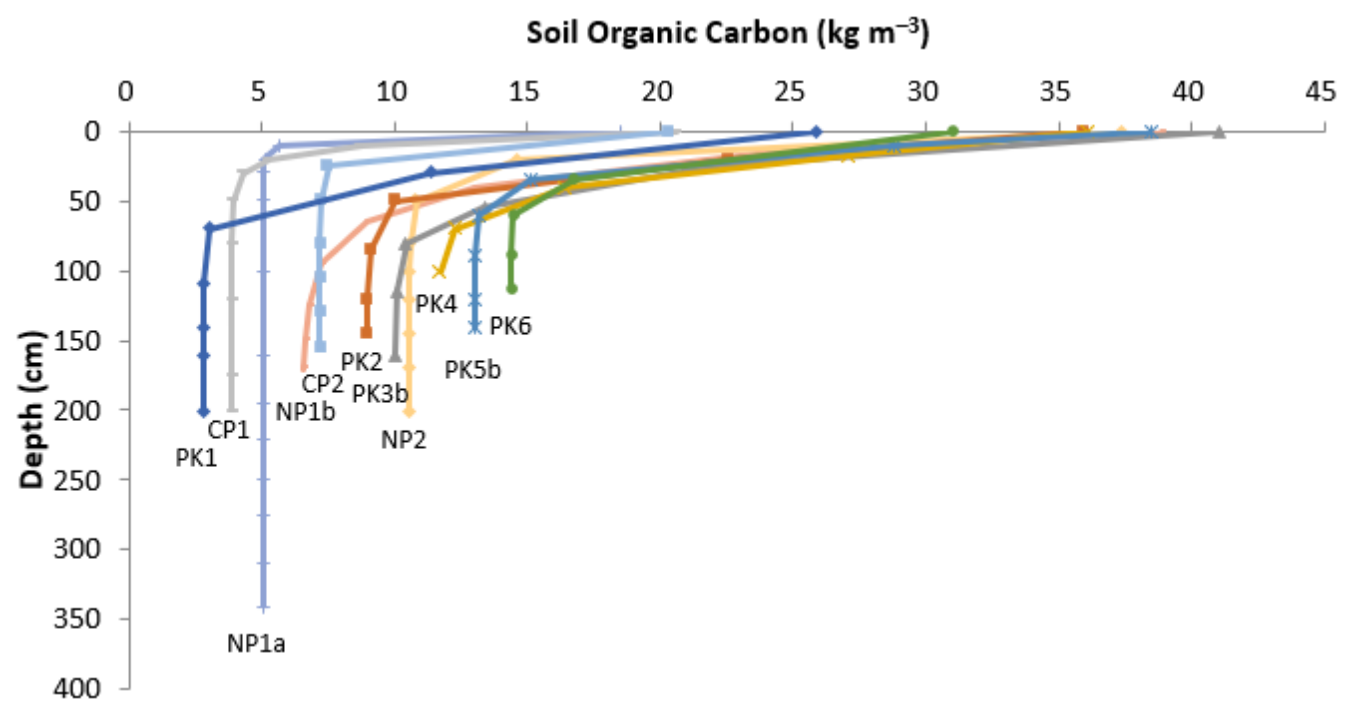

Figure 3. Pakua tableland SOC negative exponential function value variation with depth. 
The soil CSV values (Table 2) calculated in the present study decreased in the following order: PK6 $>$ PK5b $>$ PK4 $>$ NP2 $>$ PK3b $>$ PK2 $>$ CP2 $>$ NP1b $>$ NP1a $>$ CP1 $>$ PK1. The soil chronosequence based on the soil ages, from high to low, had the following order: PK1 $>$ NP1a $>$ PK2 $>$ PK3b $>$ PK4 $>$ PK5b $>$ PK6 (Table 2). The order of the sequence is the opposite of that observed from the CSV values, which indicates that the two parameters are negatively correlated (Table 4 ).

Table 4. Pearson correlation analysis of the Pakua tableland data.

\begin{tabular}{cccccccc}
\hline & CSV & TCS & WCS & Age & CAR & TCS 0-30 & TCS 0-50 \\
\hline TCS & 0.377 & & & & & & \\
WCS & $0.814^{* *}$ & $0.682 *$ & & & & & \\
Age & $-0.915^{* *}$ & 0.021 & -0.532 & & & & \\
CAR & $0.758^{*}$ & -0.121 & 0.309 & $-0.900 * *$ & & & \\
TCS 0-30 & 0.411 & 0.519 & $0.759 * *$ & -0.032 & -0.091 & & \\
TCS 0-50 & 0.549 & $0.682^{*}$ & $0.893^{* *}$ & -0.158 & -0.008 & $0.949 * *$ & \\
TCS 0-100 & $0.661^{*}$ & $0.727^{*}$ & $0.960^{* *}$ & -0.320 & 0.158 & $0.878^{* *}$ & $0.969 *$ \\
${ }^{*} p<0.05,{ }^{* *} p<0.01 ;$ statistical analysis using SPSS (version 17.0). & & &
\end{tabular}

Tsai et al. [27] analyzed the weighted mean PDI (or WPDI) and the amounts of Fe and $\mathrm{Al}$ in soils and compared them with those obtained from other studies to estimate soil and/or river terrace ages in the Pakua tableland. Soils with similar degrees of soil development were considered to be of a similar age. The soils of NP1a, NP1b, and CP1 appear to be correlated with PK1 in terms of soil age. In addition, NP2 and CP2 are equivalent to PK2 in terms of the degree of soil development and are correlated as geomorphic surfaces [18,19]. These results suggest that the soils of NP1b, CP1, and PK1 are older than those of NP2, CP2, and PK2, in terms of soil formation. As seen in Figure 2, the CSV values of CP1, NP1a, and NP1b were close to that of PK1, and those of CP2 and NP2 were close to that of PK2. These results demonstrate that CSV values can be used to determine the ages of fluvial terraces on the Pakua tableland, as well as for relevant comparisons among said terraces.

The equivalent soil development of NP1b and CP1 to PK1 provides an approximate age for the former soils. Similarly, the ages of NP2 and CP2 can be approximated from PK2 $[18,19,27]$. Using a curve-fitting formula (Equation (4)) to calculate the CAR values for $\mathrm{NP} 1 \mathrm{~b}$ and CP1 yielded an accumulation rate of $0.0201 \mathrm{~g} \mathrm{~m}^{-3} \mathrm{yr}^{-1}$, and for NP2 and CP2 yielded an accumulation rate of $0.0361 \mathrm{~g} \mathrm{~m}^{-3} \mathrm{yr}^{-1}$ (Table 5).

Table 5. Accumulation rate curve-fitting formula to provide a comparison between WCS-predicted values and measured values.

\begin{tabular}{ccccccc}
\hline $\begin{array}{c}\text { Compared } \\
\text { Pedon }\end{array}$ & $\begin{array}{c}\text { Compared Equivalent } \\
\text { Pedon (Age) }\end{array}$ & $\begin{array}{c}\text { Predicted } \\
\text { CAR }\end{array}$ & $\begin{array}{c}\text { Predicted } \\
\text { WCS }\end{array}$ & Observed WCS & $\begin{array}{c}\text { Observed } \\
\text { Average WCS }\end{array}$ & Error (\%) \\
\hline NP1b & PK1 (400) & 0.0201 & 8.040 & 9.867 & 7.897 & 1.9 \\
CP1 & PK2 (335) & 0.0361 & 12.094 & 14.694 & 13.004 \\
NP2 & & & 11.314 & 7.4 \\
\hline
\end{tabular}

Unit: age (kyr), CAR $\left(\mathrm{g} \mathrm{m}^{-3} \mathrm{yr}^{-1}\right)$, WCS $\left(\mathrm{kg} \mathrm{m}^{-3}\right)$.

The SOC stocks at deep and shallow horizons were considered separately (Figure 4). The deep horizon was found to retain more carbon than the surface or shallow horizons for soils of a greater age in the study area. 


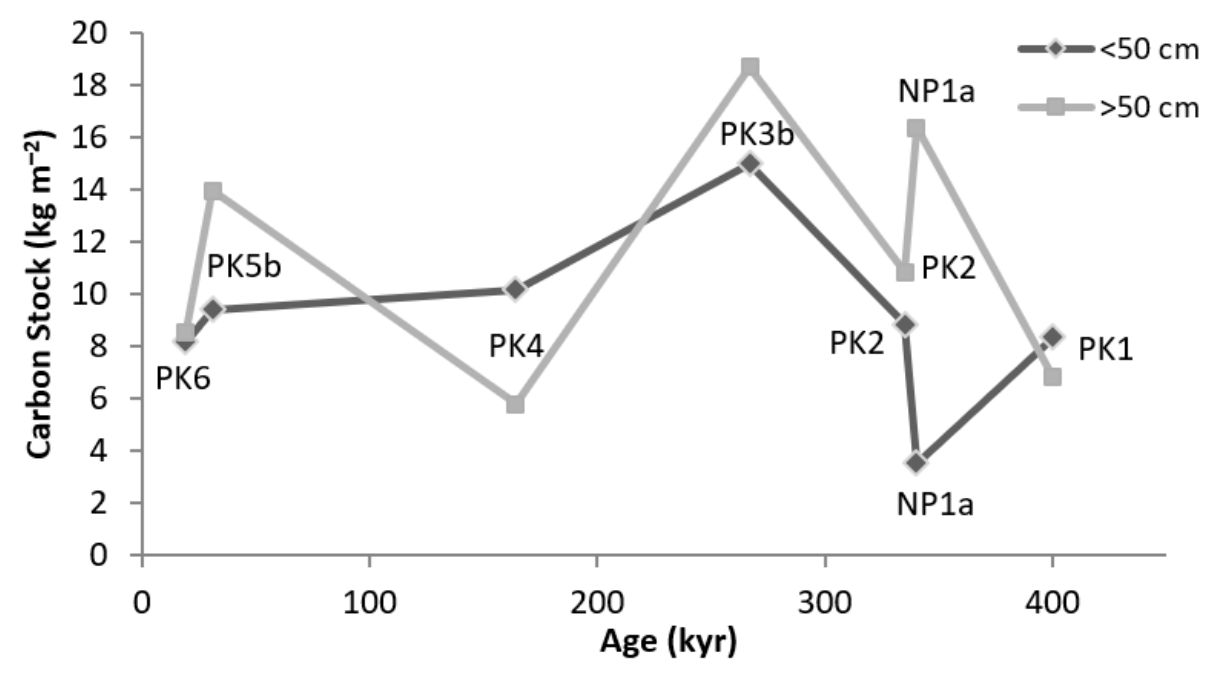

Figure 4. Data from the Pakua tableland were integrated with soil depth intervals from 0 to $50 \mathrm{~cm}$ depth (gray) and $>50 \mathrm{~cm}$ depth (black). Variables plotted include soil age and soil carbon stock.

\section{Discussion}

As a result that the study area was small, but the parent materials, vegetation, average climate, and other variables were similar in the study area, and because these variables remained fairly constant during the Pleistocene Epoch of the Quaternary Period, the soil of the terraces formed a time series that is well suited to researching long-term changes in the SOC over time. Indeed, SOC concentrations are susceptible to environmental factors, such as the climate, vegetation, time, and land use [5], with precipitation and temperature being the most influential factors [39]. Therefore, even though climate factors may influence the soil carbon sequestration rate, SOC decomposition capacities differ over time and at different soil depths. Organic matter in the subsurface horizon is characterized not only by very long turnover times but also by increasing amounts with increasing depth. Microbial activity may be reduced due to suboptimal environmental conditions, causing the microbial biomass to decrease with soil depth [14]. The present study demonstrated that the degree to which carbon decomposes in the soil differs among layers as well, and the largest discrepancies were seen in the TCS values (Table 2). The relationships between the TCS values and other variables, listed in Table 4, were insignificant. Inert organic carbon physically combines with soil matter to form red soil. Therefore, highly developed red soil in pedogenesis, which stores carbon for long periods of time (in stable quantities), can help to elucidate historical carbon-storage-related changes in the soil. The relationship between CAR values and the ages of respective Pakua tableland terraces (Figure 3) indicated that soil age is negatively correlated with the rate of carbon accumulation. In other words, CAR decreases with the soil age. This supports the notion that the decline in the quantity of soil C stored in older substrates could result from a decline in productivity and/or an increase in turnover [17]. This is especially true for shallow soil layers, which are more easily affected by the environmental factors that decompose SOC [40]. Eventually, the soil reaches an equilibrium, where the rates of carbon storage and decomposition are equal [41].

Bai et al. [34] simulated the depth distribution patterns of the SOC per volume ( $\mathrm{SOCV}$, $\mathrm{kg} \mathrm{m}^{-3}$ ) and SOC per unit area (SOCc, $\mathrm{kg} \mathrm{m}^{-2}$ ) using three mathematical functions (the exponential function, allometric function, and logistic function) and indicated that the exponential function was best suited to the analysis of the $\mathrm{SOCv}$ depth distribution. The present study utilized the same concept in regard to the WCS $\left(\mathrm{kg} \mathrm{m}^{-3}\right)$, taking into account depth distribution and using average values to depict the average carbon storage values across different soil profiles, and identified similar trends in both the WCS and TCS $(0-100 \mathrm{~cm})$, with PK3b yielding the greatest values and CP1 yielding the lowest (Table 2). Pearson's correlation analysis (Table 4) also revealed that the WCS and TCS $(0-100 \mathrm{~cm})$ were very highly correlated, which indicates that the WCS represents the average carbon 
storage value of one profile, as well as the majority of SOC storage trends. Therefore, the carbon stocks estimated by the TCS for the Pakua tableland, within a depth of $1 \mathrm{~m}$, were greater than those estimated by the WCS (Table 3). This finding is supported by the fact that more carbon is concentrated at the surface horizons [9].

The WCS predicted from the accumulation rate multiplied by age agrees well with the actual measured average WCS $\left(R^{2}=0.957\right)$. The average relative error between the predicted value and the average value of the observed value is $<4.7 \%$ (Table 5). Although the ages of the soils of some of the terraces on the Pakua tableland are not known, the comparison of the WPDI for the soils was used as an indicator of relative dating. Similarly, the average carbon stock of the terraces, estimated by curve-fitting equations, is an alternative method by which to date these soils. Toma et al. [42], in the same manner, found an SOC accumulation rate of $3.2 \mathrm{~g} \mathrm{~m}^{-2} \mathrm{yr}^{-1}$ over the past 7300 years, allowing them to determine the SOC accumulated in periods of 34, 50, and 100 years, respectively. The curve-fitting to estimate the WCS may provide age information for the soils, especially for those with the same parental material.

The present study found that SOC has a negative exponential relationship with the soil depth distribution (Figure 2) and that SOC decreases rapidly with increasing soil depth. This trend in SOC begins to slow down at a depth of 50-100 $\mathrm{cm}$ and approaches a fixed value below a certain depth. This suggests that the SOC at the deep horizon does not decompose as easily as that of shallow soil layers, and it is difficult for new SOC to accumulate at a deeper horizon. This is in line with the idea that deep SOC is recalcitrant and/or inaccessible to microbial degradation [39]. Due to a variety of influences, including the climate, temperature, and biological factors, SOC decomposes with time, leading to a reduction in the remaining SOC in the soil [39].

The concentration of red soil clay particles in the study area was fairly high $(>40 \%)[19,26,27]$, which made it relatively easy for the SOC to bind to the soil and remain there in a stable quantity [12]. Due to the pedogenesis of soil minerals over time, some minerals (e.g., halloysite) are easily bound to carbon and avoid further degradation [13]. The extent to which carbon is retained in soil depends on amorphous minerals that stabilize large amounts of organic carbon over thousands of years [17]. The SOC decreases as soil develops because there are smaller quantities of amorphous minerals in older soil. In other words, the most developed soils contain the least SOC and vice versa (Table 2). The soil's SOC accumulation rate continually decreasing with age forms a chronosequence (Figure 3). Although the total amount of SOC stored in Pakua tableland soils varied with the age of the soil, the patterns were different when SOC stocks at deep and shallow horizons were considered separately (Figure 4). The deep horizons retain more carbon than the surface or shallow horizons for the older soils in the study area, which is in line with the observations made by Lawrence et al. [13]. In contrast, less carbon is stored in the deep horizon of younger soils in the range of 19-31 kyr, which contradicts the conclusions made by Lawrence et al. [13]. This discrepancy may be due to a loss of carbon in the shallow horizons as a result of agriculture or land development [43].

In addition, the CSV is negatively correlated with soil age (Table 4). The CSV values for the area investigated in the present study demonstrated a strong correlation between the CSV and soil age, as previously reported by Lawrence et al. [13]. In order to estimate CSV values, the present study only needed to sample basic data (e.g., bulk density, organic carbon, and soil layer thickness) from the soil horizon. This method, which differs from other common river terrace chronosequence comparison methods, is more convenient and reliable. In the future, it should be possible to apply the CSV as a reference for a convenient correlation or relative dating.

\section{Conclusions}

Taiwan is located at the junction of multiple tectonic plates and, as a result, has a relatively unique topographical structure. Therefore, the study of fluvial terraces has become one of the main research topics in the study of Taiwan's environmental changes. 
Despite the fact that research technology and data have advanced substantially over the years, there are still limitations and inconveniences. Within this field, some dating materials remain difficult to obtain. The present study presents a reliable method for estimating chronosequences, which in this case was utilized in order to determine the CAR and CSVs for the study area in the Pakua tableland.

The total carbon storage calculated via total carbon stocks for the average soil profile depth was $4.5 \mathrm{Tg}$, and the carbon storage value for shallow soil $(0-100 \mathrm{~cm})$ was $3.2 \mathrm{Tg}$. The total carbon stocks calculated via weighted carbon stocks (average soil profile depth: $172 \mathrm{~cm}$ ) amounted to $4.8 \mathrm{Tg}$. When investigating the carbon accumulation rate, the value derived from weighted carbon stocks is more representative than the more commonly used total carbon stocks and is consistent with the negative relationship between the carbon accumulation rate and age for the Pakua tableland. The use of a predictive curve to estimate the average carbon storage of other profiles with the same parental sources is satisfactory. The soil organic carbon depth distribution model, based on a negative exponential function, may approximate the carbon sequestration values of deeper soil layers. For the soils of the Pakua tableland, the carbon sequestration values enabled the identification of the soil carbon chronosequence.

Supplementary Materials: The following are available online at https:/ /www.mdpi.com/article/ 10.3390/land10050447/s1. Table S1. The properties of the soil in the Pakua tableland. Figure S1. Geological map of Pakua tableland. Figure S2. Depth profiles of bulk soil. (A) Bulk density, (B) organic carbon.

Author Contributions: Conceptualization, H.T. and C.-C.H.; methodology, C.-C.H. and S.-T.H.; validation, C.-C.H., S.-T.H. and H.T.; investigation, C.-C.H., W.-S.H. and H.T.; writing-original draft preparation, C.-C.H. and H.T.; writing - review and editing, C.-C.H. and H.T.; supervision, H.T. and S.-T.H.; project administration, H.T. All authors have read and agreed to the published version of the manuscript.

Funding: This study is partially supported by MOST 109-2116-M-018-002 from the Ministry of Science and Technology of Taiwan.

Institutional Review Board Statement: Not applicable.

Informed Consent Statement: Not applicable.

Data Availability Statement: Not applicable.

Acknowledgments: The authors are grateful to Z.Y. Hseu for his valuable suggestion and discussion. The authors also thank M.F. Chen and Y.W. Wu for their assistance in the field and the chemical analyses in the laboratory. The gratitude extents to the anonymous reviewers for their comments and suggestion to enrich this article.

Conflicts of Interest: The authors declare no conflict of interest.

\section{References}

1. Tarnocai, C.; Canadell, J.G.; Schuur, E.A.G.; Kuhry, P.; Mazhitova, G.; Zimov, S. Soil organic carbon pools in the northern circumpolar permafrost region. Glob. Biogeochem. Cycles 2009, 23. [CrossRef]

2. Batjes, N.H. Total carbon and nitrogen in the soils of the world. Br. Soc. Soil Sci. Eur. J. Soil Sci. 2014, 65, 4-21. [CrossRef]

3. Lal, R. Soil carbon sequestration to mitigate climate change. Geoderma 2004, 123, 1-22. [CrossRef]

4. Bonfatti, B.R.; Hartemink, A.E.; Giasson, E. Comparing Soil C Stocks from Soil Profile Data Using Four Different Methods. In Digital Soil Morphometrics; Springer: Cham, Switzerland, 2016; pp. 315-330.

5. Brady, N.C.; Weil, R.R. The Nature and Properties of Soil, 14th ed.; Prentice-Hall: Upper Saddle River, NJ, USA, 2008.

6. Tan, Z.; Lal, R.; Smeck, N.E.; Calhoun, F.G.; Slater, B.K.; Parkinson, B.; Gehring, R.M. Taxonomic and geographic distribution of soil organic carbon pools in Ohio. Soil Sci. Soc. Am. J. 2004, 68, 1896-1904. [CrossRef]

7. Lawrence, C.R.; Harden, J.W.; Xu, X.; Schulz, M.S.; Trumbore, S.E. Long-term controls on soil organic carbon with depth and time: A case study from the Cowlitz River Chronosequence, WA USA. Geoderma 2015, 247, 73-87. [CrossRef]

8. Schmidt, M.W.I.; Torn, M.S.; Abiven, S.; Dittmar, T.; Guggenberger, G.; Janssens, I.A.; Kleber, M.; Kögel-Knabner, I.; Lehmann, J.; Manning, D.A.C.; et al. Persistence of soil organic matter as an ecosystem property. Nature 2011, 478, 49-56. [CrossRef]

9. Emerson, W.W.; Foster, R.C.; Oades, J.M. Organo-mineral complexes in relation to soil aggregation and structure. Soil Sci. Soc. Am. J. Spec. Publ. 1986, 17, 521-548. 
10. Townsend, A.R.; Vitoysek, P.M. Soil organic matter dynamics along gradients in temperature and land use on the island of Hawaii. Ecology 1995, 76, 721-733. [CrossRef]

11. Torn, M.S.; Trumbore, S.E.; Chadwick, O.A.; Vitousek, P.M.; Hendricks, D.M. Mineral control of soil organic carbon storage and turnover. Nature 1997, 389, 170-173. [CrossRef]

12. Tsai, H.; Huang, W.S.; Hseu, Z.Y. Pedogenic correlation of lateritic river terraces in central Taiwan. Geomorphology 2007, 88, 201-213. [CrossRef]

13. Huang, W.S.; Lin, W.H.; Hseu, Z.Y.; Tsai, H. Pedogenesis of Soils and their Applications of Correlations to Terraces in Northern Pakua Tableland, Central Taiwan. J. Geogr. Sci. 2011, 61, 123-145.

14. Chen, F.H.; Chen, M.Y.; Chen, W.M.; Chen, E.L. Classification and mapping of planting groups in the Baguashan tableland. Q. J. For. Res. 2007, 29, 1-14. (In Chinese)

15. Tsai, C.C.; Hu, T.E.; Lin, K.C.; Chen, Z.S. Estimation of Soil Organic Carbon Stocks in Plantation Forest Soils of Northern Taiwan. Res. Pap. Taiwan J. For. Sci. 2009, 24, 103-115. (In Chinese)

16. Huang, K.Y. The Estimation of Organic Carbon Storage in Different Soils of Taiwan. Master's Thesis, National Pingtung University of Science and Technology, Pingtung, Taiwan, 2009. (In Chinese).

17. Guo, K.S. Soil Science; China Book Company: Taipei, Taiwan, 1977. (In Chinese)

18. Bockheim, J. Soil-forming factors and Soil Taxonomy. Geoderma 1996, 226-227, 231-237. [CrossRef]

19. Gemma, T.S.; Schulte, R.P.O.; Lanigan, G.J.; Byrne, K.A.; Reidy, B.; Simó, I.; Six, J.; Creamer, R.E. Clay illuviation provides a longterm sink for C sequestration in subsoils. Sci. Rep. 2017, 7, 45635.

20. Ho, C.S. Introduction to Taiwan Geology; Central Geological Survey, Ministry of Economic Affairs: New Taipei City, Taiwan, 1997; Volume 164. (In Chinese)

21. Lee, J.C.; Lu, C.Y.; Chu, H.T.; Delcaillau, B.; Angelier, J.; Deffontaines, B. Active deformation and paleostressanalysis in the Pakua anticline area, western Taiwan. Terr. Atmos. Ocean. Sci. 1996, 7, 431-446. [CrossRef]

22. Ho, H.C.; Chen, M.M. One in 50,000 of Taiwan's Explanatory Text of the Geological Map, No.24, Taichung; Central Geological Survey, Ministry of Economic Affairs: New Taipei City, Taiwan, 2000. (In Chinese)

23. Shih, T.T.; Yang, G.S. The Active Faults and Geomorphic Surfaces of Pakua Tableland in Taiwan. Natl. Taiwan Norm. Univ. Geogr. Res. Rep. 1985, 11, 173-186. (In Chinese)

24. Simoes, M.; Avouac, P.J.; Chen, Y.G.; Singhvi, A.K.; Wang, C.Y.; Jaiswal, M.; Chan, Y.C.; Bernard, S. Kinematic analysis of the Pakuashan fault tip fold, west central Taiwan: Shortening rate and age of folding inception. J. Geophys. Res. 2007, 112. [CrossRef]

25. Chang, C.T.; Duh, C.Z.; Chiou, C.Z.; Wang, C.P. A review on the forest soil organic carbon stock in Taiwan. Q. J. Chin. For. 2007, 40, 261-273. (In Chinese)

26. Tsai, H.; Hseu, Z.Y.; Huang, W.S.; Chen, Z.S. A river terrace soil chronosequence of the Pakua tableland in central Taiwan. Soil Sci. 2006, 171, 161-179. [CrossRef]

27. Tsai, H.; Huang, W.S.; Hseu, Z.Y.; Chen, Z.S. Pedogenic approach to resolving the geomorphic evolution of the Pakua river terraces in central Taiwan. Geomorphology 2007, 83, 14-28. [CrossRef]

28. Vreeken, W.J. Principal kinds of chronosequences and their significance in soil history. J. Soil Sci. 1975, 26, 378-394. [CrossRef]

29. Liew, P.M. Quaternary stratigraphy in western Taiwan: Palynological correlation. Proc. Geol. Soc. China. 1988, 31, 169-180.

30. Hsu, C.C.; Huang, W.S.; Tsai, H.; Huang, S.T. A chronosequence of the deep soil carbon storage-an example of fluvial terraces on the southern of Pakua tableland in central Taiwan. J. Geogr. Sci. 2020. in press. (In Chinese)

31. Blake, G.R.; Hartge, K.H. Bulk density. In Methods of Soil Analysis, Part 1. Physical and Mineralogical Methods Agronomy Monograph; Klut, A., Ed.; American Society of Agronomy—Soil Science Society of America: Madison, WI, USA, 1986; Volume 9, pp. 363-375.

32. Nelson, D.W.; Sommers, L.E. Total carbon, organic carbon, and organic matter. In Methods of Soil Analysis, Part 2. Chemical and Microbiological Properties; Agronomy monograph No. 9; Page, L.A., Ed.; American Society of Agronomy-Soil Science Society of America: Madison, WI, USA, 1982; pp. 539-577.

33. Dorji, T.; Odeh, I.O.A.; Field, D.J. Vertical Distribution of Soil Organic Carbon Density in Relation to Land Use/Cover, Altitude and Slope Aspect in the Eastern Himalayas. Land 2014, 3, 1232-1250. [CrossRef]

34. Bai, J.; Zhang, G.; Zhao, Q.; Lu, Q.; Jia, J.; Cui, B.; Liu, X. Depth-distribution patterns and control of soil organic carbon in coastal salt marshes with different plant covers. Sci. Rep. 2016, 6, 34835. [CrossRef] [PubMed]

35. Minasny, B.; McBratney, A.B.; Mendonça-Santos, M.L.; Odeh, I.O.A.; Guyon, B. Prediction and digital mapping of soil carbon storage in the Lower Namoi Valley. Aust. J. Soil Res. 2006, 44, 233. [CrossRef]

36. Franzluebbers, A.J. Depth distribution of soil organic carbon as a signature of soil quality. In Proceedings of the 201019 th World Congress of Soil Science, Brisbane, Australia, 1-6 August 2010.

37. Harden, J.W. A quantitative index of soil development from field descriptions, examples from a chronosequence in Central California. Geoderma 1982, 28, 1-28. [CrossRef]

38. Birkeland, P.W. Soil and Geomophology, 3rd ed.; University Press: New York, NY, USA; Oxford, UK, 1999.

39. Jobbagy, E.G.; Jackson, R.B. The Vertical Distribution of Soil Organic Carbon and Its Relation to Climate and Vegetation. Ecol. Appl. 2000, 10, 423-436.

40. Rumpel, C.; Kögel-Knabner, I. Deep soil organic matter-a key but poorly understood component of terrestrial C cycle. Plant Soil. 2011, 338, 143-158. [CrossRef]

41. Lal, R. Carbon sequestration in soil. Philos. Trans. R. Soc. Biol. Sci. 2008, 363, 815-830. [CrossRef] [PubMed] 
42. Toma, Y.; Clifton-Brown, J.; Sugiyama, S.; Nakaboh, M.; Hatano, R.; Fernández, F.; Stewart, J.R.; Nishiwaki, A.; Yamada, T. Soil carbon stocks and carbon sequestration rates in seminatural grassland in Aso region, Kumamoto, Southern Japan. Glob. Chang. Biol. 2013, 19, 1676-1687. [CrossRef] [PubMed]

43. Delgado-Baquerizo, M.; Eldridge, D.J.; Maestre, F.T.; Karunaratne, S.B.; Trivedi, P.; Reich, P.B.; Singh, B.K. Climate legacies drive global soil carbon stocks in terrestrial ecosystems. Sci. Adv. 2017, 3, e1602008. [CrossRef] [PubMed] 